Maria Obojska*

\title{
What's in a name? Identity, indexicality and name-change in an immigrant context
}

\author{
https://doi.org/10.1515/eujal-2020-0004
}

\begin{abstract}
The present study explores the case of a transnational Polish family in Norway in which one of the care givers as well as the teenage son underwent a name change after their initial experiences of migration. Drawing on the audiorecorded interactions in the interview situation, the article investigates the identity constructions of the focal participant in his narrative about the name change. To this end, first, the indexicalities of the social identity category Pole as constructed in Norwegian media and the participants' accounts are outlined. Then, against this backdrop, the focal participant's identity claims as occasioned in the narrative on the name change are discursively analyzed. The analysis shows that the identity claims the focal participant makes aim at dissociating himself from the powerless, stigmatized position of a migrant, in which he was cast upon his arrival in Norway. Furthermore, the study suggests that migrant identity constructions need to be considered against the participants' lived experiences of migration, larger societal discourses and against participants' constructions of belonging to imagined communities.
\end{abstract}

Keywords: Identity, Indexicality, Poles in Norway, narrative

Podsumowanie: Niniejszy artykuł analizuje przypadek transnarodowej polskiej rodziny mieszkającej w Norwegii, w której zarówno jeden z opiekunów, jak i nastoletni syn zdecydowali się zmodyfikować swoje imiona na skutek doświadczeń migracyjnych. Wykorzystując audio nagrania interakcji zebranych podczas wywiadu z rodziną, artykuł analizuje, w jaki sposób główny uczestnik badania konstruował swoją tożsamość w narracji o zmianie imienia. W tym celu, po pierwsze, artykuł przedstawia indeksy kategorii społecznej 'Polak' obecne zarówno w norweskich mediach, jak i w wypowiedziach uczestników wywiadu. Następnie, z uwzględnieniem tego tła, historia zmiany imienia zostaje poddana analizie dyskursu. Analiza wykazuje, że główny uczestnik badania w swoich konstrukcjach tożsamości odcina się od tożsamości napiętnowanego społecznie, bezbronnego

*Corresponding author: Dr. Maria Obojska, Faculty of Humanities, Education and Social Sciences, Institute for Research on Multilingualism, University of Luxembourg, Avenue de l’Université, Belval, L-4369, Luxembourg, E-Mail: maria.obojska@uni.lu 
migranta, która została mu przypisana przez najbliższe otoczenie po przyjeździe do Norwegii. Ponadto, artkuł postuluje, aby rozważać konstrukcje tożsamości wśród migrantów w oparciu o ich doświadczenia migracyjne, dyskursy społeczne oraz ich konstrukcje przynależności do wspólnot wyobrażonych.

Zusammenfassung: Die Studie untersucht den Fall einer transnationalen polnischen Familie in Norwegen, in der sowohl ein Elternteil als auch der Sohn ihre Namen infolge der Migrationserfahrungen geändert haben. Der Artikel basiert auf Interviewdaten und untersucht Identitätskonstruktionen des zentralen Teilnehmers - des Vaters - in seinem Bericht über die Namensänderung. Zu diesem Zweck werden zunächst die in den norwegischen Medien und Teilnehmerbeiträgen erstellten Indexe der sozialen Identitätskategorie 'Pole' analysiert. Vor diesem Hintergrund werden dann die Identitätsansprüche des Hauptteilnehmers, wie sie in seinem Bericht über die Namensänderung auftreten, mit diskursanalytischen Methoden analysiert. Die Analyse zeigt, dass der Hauptteilnehmer sich durch seine Identitätskonstruktionen von der machtlosen, stigmatisierten Position eines Migranten zu distanzieren versucht, die ihm bei seiner Ankunft in Norwegen zugeschrieben wurde. Darüber hinaus zeigt der untersuchte Fall, dass die Identitätskonstruktionen von Migranten im Kontext ihrer gelebten Migrationserfahrungen, der gesellschaftlichen Diskurse und der Konstruktionen ihrer Zugehörigkeit zu imaginären Gemeinschaften analysiert werden sollen.

\section{Introduction}

Names are not neutral and, in different contexts, may index a variety of personal properties, such as gender, ethnicity, group belonging, religious affiliation and social status. Names are then inevitably social in their nature - on the one hand, they are socially constituted through various interactions; on the other hand, they express social relations (Khosravi 2011). In immigrant contexts foreign-sounding names become markers of differentiation and may index stigmatized social identities (Bursell 2012). Research into migrants' name changing practices suggests that individuals with foreign-sounding names may choose to adopt more locally sounding names as a destigmatization strategy. This may be done in order to: facilitate own integration into the host society, diminish the experienced discrimination, avoid negative stereotyping, increase their chances on the job market but also to express own identification with the imagined host communities (e.g. Bursell 2012; Khosravi 2011; Kim 2007; Souto-Manning 2007).

The present study explores the case of a transnational Polish family in Norway in which one of the caregivers as well as the teenage son underwent a name 
change after initial experiences of migration. In particular, drawing predominantly on the data from the interview with one of the caregivers, the article seeks to shed light on the processes of identity construction that were at work in the interview narrative on the name-change decision. To this end, I first briefly introduce the key facts and characteristics of Polish migration to Norway, taking into consideration wider societal discourses on Polish migrants. Thereafter, I present some theoretical considerations related to narratives in the interview data, with a particular focus on the interactional construction of identities. In the data analysis section, I first analyze the indexicalities of the identity category Pole as constructed by the participants in the interview. Thereafter, the analysis zooms in on the identities constructed by the focal participant in his account of the namechange. Finally, I discuss the study findings in relation to empirical and theoretical insights from the research on migrant identities.

\section{Poles in Norway: migration and discourses}

Recent political and economic changes in Europe have resulted in an increased mobility of many Polish nationals. Due to the geographical proximity and favorable working conditions, many of the recent Polish migrants have chosen Norway as the country of destination. Already in 2008, Poles became the largest group of immigrants in Norway and have maintained this status to date (Statistics Norway 2016). At the moment the Poles constitute ca. $15 \%$ of all the migrants in Norway, with roughly 100000 Polish nationals living in the country. Initially, Polish migrations to Norway had a rather fluid and transient character, with few people planning to stay in Norway permanently. However, the opportunities offered by, for example, the construction and health service sectors of the Norwegian job market paired with attractive salaries and a highly developed social welfare system enticed many workers to settle down and bring their families to Norway (Polish Ministry of Foreign Affairs 2013). Consequently, between 2006 and 2018 Poland was the top country for family reunifications in Norway (Bell and Erdal 2015; Slany and Strzemecka 2015; Statistics Norway 2016).

The level of employment among Poles in Norway aged 15-71 is high and lay at $72 \%$ as of March 2017 (Statistics Norway 2017). However, as noted in the (2013) report from the Polish Ministry of Foreign Affairs, Poles in Norway are predominantly employed in the construction industry, processing industry, health-care and cleaning services, often below their qualifications. Poles in Norway also tend to be employed through agencies, working on short-term, temporary contracts.

Research on Polish migration to Norway draws attention to various issues affecting the Polish migrants, e.g.: social dumping (Friberg and Eldring 2011; Tor- 
vatn and Pettersen Buvik 2011), negative stereotypes and language barriers (Engebrigtsen et al. 2017; Guribye et al. 2015). Taken together, these issues negatively affect social mobility and prevent the Polish migrants from establishing social capital in the new country. According to Friberg (2011), Norwegian employers tend to see Polish workers as "cheap, docile, flexible labour" and perpetuate the image of a "hard-working Pole". This happens to the extent that, according to Friberg (2011: 1931), the word Pole in Norwegian is no longer only a marker of a particular nationality but also indexes a particular position in the Norwegian labor market. Similarly, polakkarbeid 'Poles' work' refers to certain types of physical work (Dyrlid 2018).

The image of Polish migrants in Norwegian media corresponds to a large extent with the research findings reported above. Polish migrants tend to be portrayed as hard workers, with little knowledge of Norwegian, doing low-skilled and low-paid jobs, often living and working in precarious conditions. A systematic review of media representations of Polish migrants in Norway was conducted by Dyrlid (2018). In her thematic analysis of newspaper articles she identified three ways in which Polish migrants are positioned as subjects in Norwegian media discourses: the vulnerable, the hard-workers and the strangers. According to Dyrlid (2018: 141), all these subject positions underscore the differences between Polish and Norwegian employees by constructing the Poles as outsiders who are prone to exploitation and who have particular work-ethics. Further, a review of national and regional newspaper articles from 2016 conducted for the purposes of the MultiFam ${ }^{1}$ project at the University of Oslo showed that Polish immigrants were mostly represented in articles reporting on criminal activity (smuggling), traffic accidents (drink driving) and physical labor (Finstad Berg, personal communication, 2017).

\section{Narrative identities}

Definitions of identity or identities vary greatly depending on the research tradition. In this paper, identities are understood in line with social constructionism as "constructed, validated, and offered through discourses available to individuals at a particular point in time and place" (Pavlenko and Blackledge 2004: 14). Thus, identities deployed in interactions are understood as performative, fluid and dialogically co-constructed rather than fixed and predetermined. At the same time,

1 See also: https://www.hf.uio.no/multiling/english/projects/flagship-projects/multifam-family -language-policy-in-multilingual-transcultural-families/ 
these micro identities, which are situationally occasioned and negotiated in interactions, are also discursively embedded, i.e. discourses provide the terms and linguistic means of identity construction and link them to certain recognizable social personas (such as e.g. a teacher, a husband, an immigrant, etc.), which I will refer here to as macro identities. This conceptualization of identity strives, on the one hand, for a close engagement with micro level of interaction, and, on the other hand, for deepening the understanding of how the local relates to the global, i.e. societal discourses and ideologies. (cf. De Fina \& Georgakopoulou, 2011).

This relationship between the local and the global can be understood through the lens of indexicality (Silverstein, 1979, 2003), which denotes the conventionalized relationship between certain linguistic forms and social meanings (Jaffe 2016; Ochs 1993). Bucholtz and Hall (2005: 593), in their discussion of principles for the study of identity, propose the mechanism of indexicality as fundamental for interactional constructions of identities. In particular, according to Bucholtz and Hall (2005: 594), identities are constituted through several indexical processes, which could be summarized as follows: 1) overt categorization and labeling, 2) implicatures about own and other's positioning, 3) stances towards ongoing talk, interactional footings and participant roles, 4) use of linguistic means associated with particular personas/groups. These indexical processes link the micro identity constructions achieved through the situated use of particular means of meaning making to the larger aspects of the social world, i.e. macro identity categories.

As noted by Lanza (2012: 287), "narratives provide a window to the study of identity". Indeed, the intersections of narrative and identity have been explored by various scholars from many different angles, the two main traditions being: autobiographical and conversation-analytic/ethnomethodological one (De Fina 2003). Within the first paradigm, the focus falls on the processes of (re-)constructions of the self, often understood as processual and reflexive, in retellings of personal experiences (e.g. Brockmeier \& Carbaugh 2001; Mishler 2004). In the second paradigm, identity is seen as primarily relevant and emergent in interactions (e.g. Antaki and Widdicombe 1998; Wilkinson and Kitzinger 2003). The processes of identity negotiation are often understood here as interactional attempts to ascribe, assume or reject certain identity categories. In this paradigm, identities are fleeting, situationally-occasioned and context-dependent, with virtually no relevance outside of the given interaction.

In this article, the focus of analysis is two-fold. On the one hand, close attention is paid to the interactional moves aiming at certain identity claims (micro-identities). On the other hand, I look at how through the local interactional identity constructions the speakers position themselves vis-à-vis larger societal discourses (cf. also De Fina \& Georgakopoulou 2011; Lanza 2012). Taking into consideration the larger societal discourses is of particular importance when studying migrant narra- 
tives. As De Fina notes, while narrating stories, people respond not only to the immediate interactional context but also to socially circulated stories and images:

Thus, when immigrants present certain images of themselves or apply definitions to others, they are often reacting to what the media, or other social actors say about them. Their stories are often designed to counter negative images or to incorporate commonly held prejudice about competing groups. Interactional negotiations about identity cannot be explained without reference to these external voices. (De Fina 2003: 30)

De Fina points here to the fact that local identities are tied to and defined within the larger social and cultural formations, such as beliefs and ideologies about particular groups or categories of people. Thus, through narrating their stories, interactants can claim, reject, challenge or question the social identities (macro identities) and their embedded indexicalities, typically associated with certain groups in societal discourses. This is also where local identity negotiations provide insights into the extra-situational power-relations at play in a given context and illustrate how certain identity options may be more valued than others (see also Pavlenko and Blackledge 2004; Lanza 2012). In that sense, narratives are also useful sites for investigating the constructions and representation of group identities (cf. De Fina, 2006).

The current study investigates the identity constructions of a Polish migrant in Norway in his narration of a post-migration name change and is committed to tracing the connections of the identities constructed by the interviewee in situ to larger discourses and ideologies circulating in the society. The analysis of the narrative focuses on how the focal participant positions himself (and/or others) in the name-change story, appealing simultaneously to larger societal discourses on Polish migrants in Norway.

\section{Participants, methods and data}

The data for this study were collected as part of a larger project investigating multilingualism among transnational Poles in Norway through interviews, online data collection and language portraits (cf. Obojska 2017, Obojska 2018, Obojska 2019a, and Obojska 2019b). The present article focuses on data generated during interviews with one family consisting of a mother, a stepfather (both in their midthirties at the time of data collection) and a 13-year old son. The family picked the collective pseudonym Norwegiophiles for the purposes of the study. In addition, each of the family members chose an individual pseudonym for themselves.

At the time of data collection, the family was living in a small town in the Oslo area. The Norwegiophiles did not all arrive in Norway at the same time. The step- 
father, Mikael, came to Norway with his mother at the age of 12 and had been living in Norway for 23 years at the time of the data collection. After some time in Norway and negative experiences at school, Mikael decided to change his Polish first name Michat into its Norwegian equivalent. The mother, Patrycja, arrived in Norway one year prior to data collection in order to live with Mikael. Jerzy Jan, Patrycja's teenage son, arrived several months after Patrycja in order to start middle school in Norway. Jerzy Jan's name was also modified after his arrival in Norway by adding the more international middle name Jan to his Polish first name Jerzy. The family first intended to change the boy's name completely, however, the state official handling the case rejected their application. After some negotiations, however, the official agreed to add the middle name.

Mikael has a degree in business and marketing and was a successful business consultant at the time of the data collection. His responsibilities consisted mainly in facilitating cooperation between Norwegian employers and Polish employees. Patrycja has a degree in journalism and worked as a communication specialist back in Poland. After migration to Norway, she could not find a job in her profession and started working at a warehouse in the local grocery store. Nevertheless, Patrycja was very enthusiastic about the immigration to Norway, hoped to find a job in the media after learning "enough Norwegian", and at the time of data collection had a blog on which she shared details of the family's new life. Patrycja's son, Jerzy Jan, went to the local middle school and was a keen basketball player.

The interview took place at the participants' home on a weekday afternoon and took altogether a little over 2 hours. Patrycja and Mikael were interviewed together, which created a rich interactional environment during the interview. Jerzy Jan was interviewed on his own with the caregivers present in the house after he came back from his basketball training. At the time of the data collection, both Patrycja and Mikael were envisioning their future life in Norway. Jerzy Jan was considering either staying in Norway or emigrating to the USA to pursue a professional career in sports. In the interview, the Norwegiophiles reported to speak Polish at home. However, they also reported on having plans to switch to using Norwegian at home as soon as possible. Speaking Norwegian at home was supposed to facilitate Patrycja and Jerzy Jan's learning of the language . Patrycja admitted that it was mainly due to her that the family still spoke Polish at home, as she had difficulties in expressing herself in Norwegian.

The participants were given a choice to do the interview in Polish, English, Swedish and Norwegian or a combination of all these languages. All the family members chose Polish as the language of the interview, however, they also used Norwegian words and expressions at their convenience. The interview topics included the participants' experiences related to migration and multilingualism. The interview guide was followed flexibly in order not to disrupt the flow of con- 
versations. The Language Portrait method (Busch 2016 and Busch 2017) was used at the beginning of the interview to encourage the participants' reflection on their linguistic repertoires. The interview excerpts quoted in this paper were not directly inspired by the language portrait activity but occurred later on in the interviews. The interview provided rich data covering a range of topics related to the participants' migration trajectories, current and future language practices and family multilingualism. However, due to purpose and scope of the present article, in the remaining sections I will focus on the data relevant to the name change decisions of the participants.

\section{Analysis}

In this section I focus primarily on Mikael's identity negotiations in the namechange narrative that occurred in the interview. First, as a background to the analysis of Mikael's name-change narrative, I outline the social identity category Pole that was constructed by the Norwegiophiles in the interview. I propose to consider this identity category as a field of indexicality (Jaffe 2016) associated with particular signs and values and discuss it in relation to wider societal discourses on Polish migrants in Norway. Thereafter, I delve into the analysis of Mikael's identity negotiations as occasioned in the interview excerpt, in which he recounts his name change decision.

\subsection{Pole as a field of indexicality}

The social identity Pole that emerged in the interview can be treated as what Jaffe (2016) calls a field of indexicality, i.e. a grouping of "linguistic and semiotic variables associated with a particular social object”. In particular, throughout the interview the Norwegiophiles positioned Polish people in Norway as indexed by a range of signs including: types of occupation, social status, linguistic repertoires, income, etc. These signs are exemplified by the three interview excerpts below.

\section{Excerpt 1}

Patrycja: [...] Ja zostałam dobrze przyjęta. Norwedzy mocno doceniaja fakt, że się próbuje być niestatystycznie takim nieklasycznym Polakiem uciekajacym od Norwegii. Faktycznie jak widza trzy słowa po norwesku, widza uśmiech i taka otwartość do nich, to: oni też sq otwarci w zamian. Więc jakby też rozumiem czasami, powiem szczerze, nawet teraz pracujac na tym magazynie i widząc te starsze roczniki Polaków, co są tu lat naście, to są takie ja się śmieje takie cwaniaczki spod kantoru, które w pewnym momencie pouciekaly $z$ tej Polandii i ucza 
tych Norwegów słów nie zacytuję (.) Y: no to ich traktują tak. Dobrzy są do roboty, dobrze robiq i tak dalej.

Patrycja: [...] I was received well. Norwegians appreciate a lot that you try to be a non-statistical non-classic Pole who runs away from Norway. In fact if they see [hear] three words in Norwegian, see a smile, openness towards them so then they are open in return. So sometimes I also understand, to be honest (.) like now I am working in this warehouse and I see the older generations of Poles that have been here for several years. These are these, I say jokingly, these little slyboots from in front of the exchange office who at some point escaped that Polandia and they teach these Norwegians words I am not going to cite. U:m so they are treated like (.) they are good for hard work, they work fine and so on [...]

In Excerpt 1, Patrycja creates two contrasting images of Poles in Norway, which we can dub here after her the classic Pole and the non-classic Pole. Patrycja clearly aligns with the non-classic Pole, who learns Norwegian, is enthusiastic and open towards the Norwegian society. This image is set against the implicit construction of the classic Pole who, by contrast, rejects the Norwegian society and values and does not learn the language. This implicit construction is complemented by a vivid and humorous representation of classic Poles working together with Patrycja in the warehouse. Here, the classic Pole gets some additional attributes: it is a person who has been in Norway for a longer period of time and is a somewhat dubious (and funny) character.

The shady and comical persona of a classic Pole is constructed through the image of cwaniaczki spod kantoru "little slyboots from in front of the exchange office' who flee Poland and come to Norway to teach Norwegians Polish swear words. The image of the little slyboots from in front of the exchange office is taken most likely from the Polish media, which every now and then report on the cases of small criminals who prey on naïve potential clients of exchange offices by offering them very good exchange rates only to cheat on them. Interestingly, Patrycja not only distances herself from the classic Poles but also from Poland by referring to the country through the humorous neologism as Polandia. In Patrycja's narrative both classic and non-classic Poles do menial jobs in Norway but are supposedly treated differently by Norwegians. The classic ones, according to Patrycja, are mostly seen as fit for little more than hard work. The non-classic ones, herself included, are treated by Norwegians with openness. In Patrycja's account the classic Poles are the dominant type in Norway, while the non-classic ones are an exception.

\section{Excerpt 2}

Mikael: [...] Jeśli ktoś porozmawia z norweskim stolarzem albo norweskim malarzem, no to przypuszczam, że on nie jest wniebowzięty. A jeśli się porozmawia ktoś na wyższych stanowiskach typu biurowych np. co Polacy mu remontuja dom za 100 koron na godzinę, to jest wnie- 
bowzięty. Że ktoś ma sprzątaczkę z Polski, co też mu sprząta dom za jedna tam dziesiąta ceny. Też jest wniebowzięty.

Mikael: if somebody talks to a Norwegian carpenter or painter then I suppose they are not over the moon. But when you talk to somebody who has a higher position, working in an office, and for instance Poles renovate his house for 100 crowns an hour, then he will be over the moon. And if somebody has a cleaner from Poland who cleans his house for one tenth of the price, then he is also over the moon.

In Excerpt 2, Mikael talks about Norwegians' attitudes towards Polish migrants and by doing so also attributes specific indexicalities to the field Pole. In Mikael's account, Poles are mostly cast as a cheap labor force in Norway, whose competitive prices are a worry for local manual workers and a bargain for Norwegian clients. Mikael's account also typifies traditional Polish gender roles: the renovation workers in his utterance are males (Polacy), whereas the cleaner is a female (sprzątaczka).

\section{Excerpt 3}

Mikael: [...] Kiedyś za obcokrajowca się uważało po prostu Norwegów z pótnocy. To była jak gdyby taka klasa, klasa jak gdyby, to byli uchodźcy i Norwedzy z pótnocy. Właśnie byli wyśmiewani, wszędzie się z nich właśnie nabijali. No i Szwedzi. Tak Szwedzi to byli kiedyś Polacy, ta jak teraz na budowach, to kiedyś byli Szwedzi.

Mikael: [...] some time ago people considered Norwegians from the North to be foreigners. This was a kind of a class, a kind of class (.) well these were refugees and Norwegians from the North. They were laughed at. Everywhere people mocked them. And the Swedes. Yeah, the Swedes used to be Poles before. Like now at the construction sites (.) it used to be Swedes.

In Excerpt 3, Mikael reflects on the changes in the perceptions of foreignness in Norway and constructs Poles as the new strangers. In this account, the division between the hegemonic majority vs. minority and the unequal distribution of power comes strong to the fore. The minorities are the odd ones, the ridiculed ones and the ones who do the heavy work. In the historical development sketched by Mikael, the former minorities seem to get absorbed in the majority group after some time, while new minorities emerge. At the moment, in Mikael's account, it is the Poles who occupy the undesirable, low-prestige, minority position.

While it is beyond the aim and scope of this paper to analyze the above excerpts in full detail, they give a good sense of the sort of indices the field Pole is populated with in the Norwegiophiles' accounts. These indices correspond largely to the wider societal discourses on Polish people in Norway, including both scholarly and media representations (see Section 2 above). More specifically, these in- 
dices include: lack of competence in Norwegian, doing (hard) physical work, lowwages, low-prestige, minoritized social status. Of course, the excerpts above are as much about 'Poles' as they are about 'Norwegians' and, in fact, stress the divisions between the two groups. Here, we are touching upon minority/majority relations and the questions of power, ideology and inequality. Golden and Lanza (2013: 309-310) note that privilege in terms of access to social and linguistic resources is linked to power. In the Norwegiophiles' accounts, the social identity category Pole is a disempowered one, characterized by low social and linguistic capital. Norwegians, on the other hand, are constructed as a majority, holding economic and symbolic power. Against this backdrop, I will now turn to the analysis of the name-change narrative of the focal participant.

\subsection{Mikael's name change}

In the interview excerpt below Mikael, Patrycja and I jointly orient to his namechange after his arrival in Norway. The excerpt starts with Mikael recounting the ways he is positioned by his colleagues at work, which serves as a springboard for the name-change story. As it will be evident below, Mikael's narrative is characterized by certain disfluencies and an apparent lack of clear, logical structure. According to Gee, (2011: 162) it is a typical characteristic of “deep narratives”, in which people attempt to make sense of life experiences and important concerns. These kind of narratives often lack logical consistency, as people tend to focus in them on the theme they are trying to explore and develop rather than on the structure and coherence of the form. The informal character of the interview with Norwegiophiles may have encouraged the production of this kind of narrative by Mikael, as the interview guide was not followed strictly and instead a natural flow of conversation was preferred.

\section{Excerpt 4}

1. Mikael: jestem czasami przedstawiany jako polak, czasami jako norweg, różnie to jest. I am sometimes introduced as a Pole, sometimes as a Norwegian, it differs.

2. Maria: $\mathrm{mhm}$

3. Mikael: I tak samo norwedzy różnie na przykład <podchodzą And the Norwegians for instance also <approach differently>

4. Maria: $<$ a ty jak się> przedstawiasz? $<$ and you how $>$ do you introduce yourself?

5. Mikael: wiesz co nie wiem. (.) no jak się przedstawiam? you know I don't know. (.) Well how do I introduce myself?

6. $\quad$ czy ja wiem jak się przedstawiam? not sure how I introduce myself? 
7. Patrycja: Mikaelem jesteś. (.) już Norwegiem.

You are Mikael. (.) a Norwegian already.

8. Maria: Mikaelem? Powiedziateś <Mikael jak przyszłam>!

Mikael? You said $<$ Mikael when I came $>$ !

9. Patrycja: <tak (.) no oczywiście >

$<$ yes (.) of course>

10. Mikael: Ok (.) no ja tu zmienitem sobie imię.

Ok (.) well I changed my name here.

11. bo kiedyś na przykład nie było takie normalne (.)

because before it wasn't so normal for example (.)

12. jak Polaków nie było tutaj dużo, no to Michat też (.)

when there were not so many Poles here, so then Michał as well (.)

13. jak gdyby takie przedrzeźniania w szkole, jakieś inne takie rzeczy

so some kind of mocking at school, some other stuff like that

14. Maria: tak?

Yeah?

15. Mikael: tak. skończyly się tym, że ja podjątem decyzję (.)

Yes. It resulted in me taking the decision (.)

16. po co sobie będę utrudniat życie?

why should I make my life harder?

17. Maria: $\mathrm{mhm}$

18. Mikael: po prostu dopasuję się bardziej do sytuacji.

I will adjust more to the situation

19. I sobie po prostu, nawet w zwyktym CV,

And just, even in a simple CV,

20. jeżeli ktoś chce wysłać $\mathrm{CV}$,

if somebody wants to send a CV,

21. Patrycja: $\mathrm{mhm}$

22. Mikael: to już na samym poczatku po prostu

So at the very beginning simply

23. ktoś y: ja sobie własnym imieniem podcinam noge, somebody u:m with my own name I trip myself up

24. tak naprawdę w wejściu.

Right at the very entrance.

In lines 1-3 Mikael talks about his co-workers' perceptions of his nationality. Using the passive voice jestem przedstawiany 'I am introduced', he reports on how other people at times position him as a Norwegian and at times as a Pole. Recounting these attributed perceptions is also an act of positioning on Mikael's part and an indirect claim of a blurred Polish-Norwegian identity. This claim sparks my question in line 4, in which I challenge Mikael to make an explicit identity claim. This challenge causes some confusion on Mikael's part in lines 5-6. He expresses his uncertainty (and perhaps also discomfort and/or reluctance to explicitly position himself as either a Pole or a Norwegian) through the repeated use of the negated epistemic verb wiedzieć 'to know', frequent pauses, repeated inter- 
rogatives and rising intonation at the end of his turn. In line 7, Patrycja steps in and explicitly positions Mikael as a Norwegian. At the same time, she makes an indexical link between the norwegianized form of the name 'Mikael' and the name-bearer's Norwegian ethnicity. In the light of the overall indexicalities of the fields Pole and Norwegian, as emerged in the interview, this move is significant as it casts Mikael in the role of the empowered member of the Norwegian majority.

In my next turn in line 8, I remember that Mikael indeed introduced himself using the Norwegian form of his name when I arrived and through my exclamative contribution, I reinforce the identity ascribed to Mikael by Patrycja. In an overlapping turn in line 9, Patrycja aligns with me using the emphatic affirmative phrase tak, no oczywiście 'yes, of course' and thus further strengthens Mikael's positioning as a Norwegian. In response, Mikael accepts this identity by the affirmative 'Ok'. This fragment illustrates well the co-constructed character of identities in interviews - the participants' identity claims are always situated in concrete interview interactions and are thus affected by the contributions of the other interactants. Lanza (2012) made a similar point in her analysis of a Filipino migrant's identity constructions, in which she showed that the participants' constructions of empowered identity were substantially supported by the interviewer and the research assistant.

In line 10, using active voice Mikael asserts that he changed his name after arrival in Norway and claims an agentive identity for himself. As noted by Ahearn (2010), agency in language can be encoded in two ways: grammatically and through meta-agentive discourse, i.e. talk about one's own and others' actions, the attribution of responsibility for events and the representations of decisionmaking processes. These two levels are often intertwined, and so indeed, Mikael's agentive identity claim in line 10 is encoded on both levels: grammatically, through him being both the syntactic subject and semantic agent of the sentence, and discursively, through stressing Mikael's initiative and responsibility in the name-change process.

In line 11-12, Mikael sketches the context for the name change alluding that in the past Norway was not a multicultural country and foreign names, like his own Polish one, Michat, were markers of differentiation. In line 13, he gives an explicit reason for the name change - instances of bullying at school. His narrative is briefly interrupted by my expression of surprise tak?, which invites Mikael to share further details. In line 15, Mikael makes the causal relationship between the instances of bullying and his decision to change his name explicit. Interestingly, although it is clear from the context that Mikael was the victim of bullying, most likely staged by the students belonging to the Norwegian majority, his contributions in line 11-13 lack personal pronouns and specific designation of semantic agent and patient roles. This may suggest Mikael's reluctance to assume the victim 
position. Indeed, in line 15, he switches back to the use of the first person pronoun, claiming his own responsibility and agency in the name-change decision.

In lines 16 and 18, Mikael quotes his inner speech and further explicates the rationale behind the name change, this time making an implicit connection between having a foreign name and making one's life 'harder'. Here, the namechange decision becomes a survival strategy, allowing Mikael to blend in ('adjust to the situation'). In lines 19-24, he goes even further and, through the unconventional use of the idiom podcinać komuś nogi 'trip somebody up', constructs foreign names as obstacles potentially limiting one's chances on the job market. Usually, the phrase expresses a semantic agent-patient relationship and may mean 'make somebody fall' or 'make somebody fail'. Here, Mikael uses the phrase in a reflexive way, making himself both the semantic agent and patient, and implying that by carrying a foreign name he would contribute to his own social failure.

In her study of undocumented Mexican immigrants' narratives, De Fina (2003) found that stories in which ethnic identification plays a role are usually built around a common structure: an antagonist performs some kind of an aggressive action against the narrator, who himself is constructed as not able to react. Mikael's narrative does not conform to this structure, although in the interview excerpt the identity categories Pole and Norwegian are made relevant. In Mikael's story, the instances of bullying are recounted in nominal phrases (takie przedrzeźniania $w$ szkole, jakieś inne takie rzeczy), in which the perpetrators are not given any particular persona, although we may infer that they were in fact majority students. This also allows Mikael to avoid casting himself as a victim. Instead, he assumes an identity of an agentive individual capable of reacting and undertaking counter-actions, such as a name-change.

\section{Discussion and conclusions}

Mikael's name-change decision as recounted in his narrative is interwoven primarily with his lived experiences of migration. In the name change story, Mikael constructs two identities. The first one, associated with the Polish name, is an identity of a disempowered, bullied and marginalized migrant, rejected by the members of the majority. In Mikael's account, this identity belongs to the past and as well as the episodes of discrimination he experienced at school. Mikael dissociates himself from this identity by constructing an opposing one - that of an agentive decision maker who launches his own name change and who thereby gains access to social resources. Al Zidjaly (2009: 178) notes that agency is inseparable from power, as the capacity to act lies at the core of the ability to exert power. 
Thus, through the meta-agentive discourse on name-change, Mikael constructs a powerful identity for himself in the story world.

However, Mikael made identity claims not only in the story world but also in the interview world. In order to understand these, it is necessary to consider the indexicalities of the social identity category Pole that emerged both in the interviews with the Norwegiophiles and in societal discourses in Norway. As noted in section 2, Poles tend to be represented in Norwegian media as low-paid, easily exploited physical workers with limited linguistic repertoires (see also Dyrlid 2018). A similar image is also constructed in the academic discourse (see e.g. Engebrigtsen et al. 2017; Friberg 2011; Friberg and Eldring 2011; Torvatn and Pettersen Buvik 2011; Guribye et al. 2015). These indexicalities were reproduced to a large extent by the Norwegiophiles in the interview (see Section 5.1). Hence, the identity category Pole as both constructed in the interview and in societal discourses is characterized by a lack of power and prestige, a marginalized social position and a limited access to symbolic and economic resources.

In this context, Mikael's lack of alignment with this identity category and aiming at an in-between identity at the beginning of Excerpt 4 are not surprising. Importantly, Mikael does not make any explicit claims of a Norwegian identity either. On the one hand, this could have been influenced by the particular interview situation, in which Mikael was interacting with Patrycja and the researcher both of whom identified as Polish. On the other hand, it could signal Mikael's claim of a hybrid, Polish-Norwegian identity. Initially he avoids self-categorization and reports instead on the shifting Polish-Norwegian identities ascribed to him by others. When confronted with my question on his self-categorization, he expresses uncertainty and shows reluctance to explicitly position himself as either a Norwegian or a Pole. This could be a sign that Mikael perhaps experiences a conflict between the two identities. However, he did not verbalize this tension at any time during the interview and seemed to be content with being positioned as a 'Norwegian' by Patrycja. In any case, the ascription of a Norwegian identity to Mikael was first jointly constructed by Patrycja and I (see above). Only thereafter it was ratified by Mikael himself.

In Mikael's narrative, the name change brings about a change in the macro identities available to him. Before the name change, he was the ridiculed misfit with an unusual name. The new name creates opportunities for more neutral, majority identities and fitting in (the way Mikael is positioned by Patrycja at the beginning of the excerpt attests that the name change did open up the desired majority identity for him). Thus, the old Polish name is constructed in Mikael's account as a marker of differentiation, an index of foreignness, a barrier to social and economic mobility, and as a kind of stigma. These representations resonate well with the research findings on name-change practices of migrants in Sweden. 
For example, (Khosravi 2011) found that Muslim migrants who changed their names in Sweden saw the ethnic names as obstacles to employment and career progress, and linked them to instances of discrimination. Similarly, (Bursell 2012) showed that her participants changed their names to avoid discrimination in recruitment processes and to gain social recognition.

In Mikael's story the catalyst for the name change is his school experience in Norway and the desire to fit in. Interestingly, the initial experiences of mocking and bullying at school were also recounted as the main reason for the name change of Patrycja's son, Jerzy Jan. Research on the inclusion of Polish children in Norwegian schools revealed that Polish children and their problems are largely "invisible" from the perspective of Norwegian educators and school administrators. This is partly due to the presupposed "common European background and values", partly due to the children's "European looks" and partly due to parental efforts to make their children "fit in" (Wærdahl 2016). In Wærdahl's study the efforts of the Polish parents mostly concentrated on ensuring that their children had the same kinds of school supplies, accessories and clothes as their Norwegian peers. In case of Jerzy Jan, the name change decision was initiated by the caregivers and can thus be seen as an extreme example of the parental efforts aiming at minimizing the differences between Jerzy Jan and his majority peers.

The name changes in the family are very much in line with Norwegiophiles' overall orientation towards Norway and the Norwegian society. In the interview, all family members expressed positive attitudes towards Norway and stressed their willingness to integrate. The family's enthusiasm for Norway and the Norwegian society is well captured by the pseudonym they chose for the study: Norwegiophiles. The pseudonym was originally proposed by Patrycja and immediately accepted by the other family members. It suggests the family's strong alignment with Norway as an imagined community (Anderson, 1991). Anderson's term imagined community stems from his work on nationhood and nationalism. According to him, nations are imagined communities as its members never get to know most of their fellow-members, however "in the minds of each lives the image of their communion" (1991: 6). Thus, imagining their future lives in Norway, the Norwegiophiles see themselves as connected to other members of the Norwegian society across time and space. This alignment was also stressed in the family's projected future life, in which they would speak Norwegian at home and continue living and working in Norway. In this context the Polish names may be understood as parts of the participant's multilingual repertoires, which they plan to shed as they become members of the Norwegian imagined community.

Norton (2013) argues that in the context of migration imagined communities are inherently linked to imagined identities. More precisely, the imagined communities of belonging provide enhanced opportunities for future identities. Con- 
sidering the indexicalities of the identity category Pole discussed above, the Norwegiophiles' alignment with the Norwegian imagined community and the inherent empowered, majority identity options is hardly surprising. So is shedding the indices of the undesirable identity, i.e. the Polish names. In this context the name modifications in Norwegiophiles' family can be seen as attempts to secure belonging to the desired community and access to the desired identities.

The above analyses suggests that migrant identity constructions need to be considered against the participants' lived experiences of migration, larger societal discourses and against participants' constructions of belonging to imagined communities. Mikael's account of the name-change brings to the fore the instances of mocking at school as the catalyst for name change decision. A close analysis of his identity constructions in the story world and in the interview world shows that the identity claims he makes aim at dissociating himself from the powerless, stigmatized position of a migrant, in which he was cast at school. At the same time, his interactional identity constructions position him as an empowered and agentive individual. If we follow De Fina (2004) and consider migrants' narratives to be not only responses to the immediate interactional context but also to the wider social context, then Mikael's account can be seen as a reaction to the images of Polish migrants circulating in the Norwegian societal discourses. Through the name change story, Mikael rejects the default identity of a Polish migrant and claims the right to more powerful identity options.

These more powerful identity options, however, have their source in wider societal discourses, too. As noted already in 2012 by Lanza, in spite of Norway enjoying an image of a liberal and open country with generally positive attitudes towards migration and diversity, there have been some sentiments of social rejection of people with immigrant background. These can be based on the migrants' ethnicity (see e.g. the debate on the 'ethnic Norwegian' as discussed in Lane 2009 or section 2 for more examples) and/or linguistic repertoires. For example, a recurring theme in the Norwegian public discourse have been the necessity of migrants' learning the Norwegian language and getting socialized in the Norwegian culture in order to successfully integrate in the society. In order to encourage this kind of a 'successful integration', the Norwegian right-wing parties have even put forward solutions like cutting the social welfare to migrants who do not master the language within 5 years after settling down in the country or regulating the maximum number of minority language speakers in kindergartens. It is worth noting that by shedding the indices of 'Polishness' and opting for the more neutral 'Norwegianized' identity, Mikael responds to this discourse on migration by aligning with the premises of 'successful integration' and blending in. Thus, his agency is realized through and constrained by the identity options offered in the discourses available to him at the moment of speaking. Notably, his response to 
these discourses in the name-change story perpetuates to a large extent the schematic representations of group identities applied to 'Poles' and 'Norwegians'.

Although the name changes in the Norwegiophiles' family cannot be used to generalize about the experiences of all newcomers to Norway, the case does raise a few general questions about the power relations, identity formation and integration processes in multilingual and multicultural societies. Pavlenko and Blackledge (2003: 3) note that identity "negotiations" are logical outcomes of situations where some identities are "more equal than others". These negotiations become more apparent in settings where certain linguistic resources and identity options are more valued than other ones. In the Norwegian setting, the identity options linked to the category Pole are associated with low social capital and agency, thus becoming less desirable than the empowered majority identity options. In this study, Mikael responded to these inequalities by resisting the identity category Pole and engaging in a construction of an alternative identity in the interview. In Mikael's narrative, this struggle for more power and equality represented an important part of his name-change decision. The decision itself can be viewed as a move aiming at a full majority belonging and integration into the Norwegian society. This makes Mikael's case fall into a common pattern in migration experiences of many. As noted by Kalocsanyiova (2019), although the rhetoric of integration often presents it as a two-way process of accommodation between the newcomers and the host society, in reality the ultimate responsibility for a successful adjustment falls on migrant individuals themselves. Bringing experiences of migrants such as Mikael and his family to light, could contribute to raising awareness among members of the majority society and, hopefully, to more social justice and equality in multicultural and multilingual settings.

Acknowledgements: This work was supported by the Luxembourg National Research Fund PRIDE15/10921377/CALIDIE/Hu.

I would like to thank the Norwegiophiles for sharing their stories with me. I am also very grateful to Adelheid Hu, Ingrid De Saint-Georges and the two anonymous reviewers for close reading and comments on earlier versions of this text.

Funding: The writing of this paper was partly supported by the Research Council of Norway through its Centres of Excellence funding scheme, project number 223265 (MultiLing) and 240725 (MultiFam), as well as by Fonds National de la Recherche Luxembourg through the CALIDIE project PRIDE15/10921377/CALIDIE/Hu.

\section{Transcription conventions}

(.) pause

, brief pause 


$\begin{array}{ll}. & \text { Falling intonation } \\ ? & \text { rising intonation } \\ ! & \text { exclamation } \\ <\ldots> & \text { overlapping speech } \\ : & \text { elongated sound } \\ @ & \text { laughter } \\ \text { Bold }- & \text { emphasis } \\ \text { Italic }- & \text { Polish original } \\ \text { Underline } & - \text { Norwegian }\end{array}$

\section{References}

Ahearn, L. M. (2010). Agency and language. In J. Jaspers, J.-O. Östman, \& J. Verschueren (Eds.), Handbook of Pragmatics Highlights (Vol. 7, pp. 28-48). John Benjamins Publishing Company. https://doi.org/10.1075/hoph.7.03ahe

Al Zidjaly, N. (2009). Agency as an interactive achievement. Language in Society, 38(2), 177-200. https://doi.org/10.1017/S0047404509090320

Anderson, B. (1991). Imagined Communities: Reflections on the Origin and Spread of Nationalism. Verso.

Antaki, C., \& Widdicombe, S. (1998). Identities in Talk. SAGE.

Bell, J., \& Erdal, M. (2015). Limited but Enduring Transnational Ties? Transnational Family Life Among Polish Migrants in Norway. Studia Migracyjne - Przegląd Polonijny, 157(3).

Brockmeier, J., \& Carbaugh, D. (Eds.). (2001). Studies in narrative. Narrative and identity: Studies in autobiography, self and culture. John Benjamins Publishing Company.

Bucholtz, M., \& Hall, K. (2005). Identity and interaction: A sociocultural linguistic approach. Discourse Studies, 7(4-5), 585-614. https://doi.org/10.1177/1461445605054407

Bursell, M. (2012). Name change and destigmatization among Middle Eastern immigrants in Sweden. Ethnic and Racial Studies, 35(3), 471-487. https://doi.org/10.1080/01419870.20 11.589522

Busch, B. (2016). Methodology in biographical approaches in applied linguistics. https://www.academia.edu/20211841/WP187_Busch_2016._Methodology_in_biographica I_approaches_in_applied_linguistics

Busch, B. (2017). Expanding the Notion of the Linguistic Repertoire: On the Concept of Spracherleben-The Lived Experience of Language. Applied Linguistics, 38(3), 340-358. https://doi.org/10.1093/applin/amv030

De Fina, A. (2003). Identity in Narrative: A study of immigrant discourse (Vol. 3). John Benjamins Publishing Company. https://doi.org/10.1075/sin.3

De Fina, A. (2006). Group identity, narrative and self-representations. In A. De Fina, D. Schiffrin, \& M. Bamberg (Eds.), Discourse and Identity: (pp. 351-375). Cambridge University Press. https://www.cambridge.org/core/books/discourse-and-identity/group-identity-narrativeand-self-representations/B98A92ED49CE25379B9C2007E917B179

De Fina, A., \& Georgakopoulou, A. (2011). Analyzing Narrative: Discourse and Sociolinguistic Perspectives. Cambridge University Press. 
Dyrlid, L. M. (2018). «Polakken kan» Narrativer om polske migranters arbeid og tilhørighet $\mathrm{i}$ Norge. Norsk Antropologisk Tidsskrift, 29(3-4), 124-145.

Engebrigtsen, A., Stąpor, M., \& Andenæs, K. (2017). Small places large questions: Polish workers on short-term contracts and in low-paying jobs in Sør-Trøndelag, Norway: A study of the unmet need for legal aid (2/17). NOVA.

Finstad Berg, M. (2017). Preliminary results of research on image of Poles in Norwegian media. Private communication. [Personal communication].

Friberg, J. H. (2011). Culture at work: Polish migrants in the ethnic division of labour on Norwegian construction sites. Ethnic and Racial Studies, 35(11).

Friberg, J. H., \& Eldring, L. (2011). Polonia i Oslo 2010. Mobilitet, arbeid og levekår blant polakker $i$ hovedstaden (No. 27). FAFO.

Gee, J. P. (2011). An introduction to discourse analysis: Theory and method. (3rd ed.). Routledge.

Golden, A., \& Lanza, E. (2013). Metaphors of culture: Identity construction in migrants' narrative discourse. Intercultural Pragmatics, 10(2), 295-314. https://doi.org/10.1515/ip-2013-0013

Guribye, E., Kvamme, I., Zyzak, B., \& Zyzak, D. (2015). Social capital among Polish immigrant families in Norway (TRANSFAM: Progress report Work Package 3). http://www.transfam.soc jologia.uj.edu.pl/documents/32445283/3cc1226f-5149-48ac-97b1-07afade19e76

Jaffe, A. (2016). Indexicality, stance and fields in sociolinguistics. In N. Coupland (Ed.), Sociolinguistics: Theoretical Debates (pp. 86-112). Cambridge University Press; Cambridge Core. https://doi.org/10.1017/СB09781107449787.005

Khosravi, S. (2011). White masks/Muslim names: Immigrants and name-changing in Sweden. Race \& Class, 53(3), 65-80. https://doi.org/10.1177/0306396811425986

Kim, T.-Y. (2007). The Dynamics of Ethnic Name Maintenance and Change: Cases of Korean ESL Immigrants in Toronto. Journal of Multilingual and Multicultural Development, 28(2), 117-133. https://doi.org/10.2167/jmmd419.1

Lane, P. (2009). Mediating national language management: The discourse of citizenship categorization in Norwegian media. Language Policy, 8 (3), 209-225. https://doi.org/10.1007/ s10993-009-9139-6

Lanza, E. (2012). Empowering a migrant identity: Agency in narratives of a work experience in Norway. Sociolinguistic Studies, 6 (2), 285-307.

Mishler, E. G. (2004). Storylines. Harvard University Press.

Norton, P. B. (2013). Identity and Language Learning: Extending the Conversation. Multilingual Matters.

Obojska, M. (2018). Between duty and neglect: Language ideologies and stancetaking among Polish adolescents in Norway. Lingua, 208, 82-97. https://doi.org/10.1016/j.lin gua.2018.03.009

Obojska, M.A. (2017). "Are you so ashamed to come from Poland and to speak your mother tongue?" - metalinguistic talk, identities and language ideologies in teenagers' interactions on ASKfm. Multilingual Margins: A Journal of Multilingualism from the Periphery, 4(1), 27-27.

Obojska, M.A. (2019a). 'Ikke snakke norsk?' - Transnational adolescents and negotiations of family language policy explored through family interview. Multilingua, $O(0)$. https://doi.org /10.1515/multi-2018-0058

Obojska, M.A. (2019b). Trilingual repertoires, multifaceted experiences: Multilingualism among Poles in Norway. International Multilingual Research Journal, O(0), 1-20. https://doi.org/1 $0.1080 / 19313152.2019 .1611337$ 
Ochs, E. (1993). Indexing Gender. In A. Duranti \& C. Goodwin (Eds.), Rethinking Context: Language as an Interactive Phenomenon (pp. 335-358). Cambridge University Press.

Pavlenko, A., \& Blackledge, A. (2003). Negotiation of Identities in Multilingual Contexts. Multilingual Matters. http://site.ebrary.com/lib/alltitles/docDetail.action?docID=10096133

Polish Ministry of Foreign Affairs. (2013). Raport o sytuacji Polonii i Polaków za granica 2012. http://www.msz.gov.pl/resource/d44dcd91-ed03-4e64-a475-b56dbece5a46:JCR

Silverstein, M. (1979). Language structure and linguistic ideology. In P. R. Clyne, W. P. Hanks, \& C. L. Hofbauer (Eds.), The elements: A parasession on linguistic units and levels (pp. 193-247). Chicago Linguistic Society.

Silverstein, M. (2003). Indexical order and the dialectics of sociolinguistic life. Language \& Communication, 23(3), 193-229. https://doi.org/10.1016/S0271-5309(03)00013-2

Slany, K., \& Strzemecka, S. (2015). Gender Roles and Practices in Polish Migration Families in Norway through the Eyes of Children. Studia Migracyjne - Przegląd Polonijny, 157(3), 157-181.

Souto-Manning, M. (2007). Immigrant Families and Children (Re)Develop Identities in a New Context. Early Childhood Education Journal, 34(6), 399-405. https://doi.org/10.1007/ s10643-006-0146-3

Statistics Norway. (2016). More family reunifications than new marriages. Ssb.No. http://www.ssb.no/en/befolkning/artikler-og-publikasjoner/more-family-reunifications-th an-new-marriages

Torvatn, H., \& Pettersen Buvik, M. (2011). PolTrond. Arbeidsvilkår og arbeidsmiljø blant polske arbeidere i Trondheimsregionen (No. 2011-06-10). SINTEF Teknologi og ledelse.

Wærdahl, R. (2016). The Invisible Immigrant Child in the Norwegian Classroom: Losing Sight of Polish Children's Immigrant Status Through Unarticulated Differences and Behind Good Intentions. Central and Eastern European Migration Review, 5, 1-16.

Wilkinson, S., \& Kitzinger, C. (2003). Constructing identities: A feminist conversation analytic approach to positioning in action. In R. Harré \& F. Moghaddam (Eds.), The Self and Others: Positioning Individuals and Groups in Personal, Political and Cultural Contexts,. Praeger. 